\title{
Comparison of Anatomical Characteristics for Wood Damaged by Oak Wilt and Sound Wood from Quercus mongolica ${ }^{1}$
}

\author{
Woo-Seok JEON ${ }^{2} \cdot$ Hyun-Mi LEE(D ${ }^{2, \dagger} \cdot$ Ji-Hyun PARK ${ }^{3}$
}

\begin{abstract}
The aim of this study was to investigate the anatomical characteristics of Quercus mongolica infested by oak wilt disease. To analysis the anatomical characteristics of the wood specimens infested by the oak wilt, the anatomical structures of an infected wood, a dead wood, and sound wood were observed at 10-year-old intervals from 10 to 50 annual rings using both an optical and a scanning electron microscope. The fiber length was measured in units of 5 annual rings from the pith, and the diameter of the vessel element and the ratio of the vessel including the tyloses were measured for each 10 annual ring. In the cross section, on the infected and dead wood specimens, mycelium was also observed with the tyloses in the vessel. There was no signification difference between the wood specimens in the fiber length and the vessel diameter of the vessel element. The fiber length was not difference after 20-30 annual rings which is a part of juvenile wood. The average of the vessel ratio including tyloses in the infected wood was the highest. Especially, the ratio of tyloses was the highest 40-50 annual rings in the infected wood and the dead wood. Therefore, the large difference between the infested wood by oak wilt and the sound wood was the ratio of tyloses. This result can be used as a basic data to utilize the infested wood.
\end{abstract}

Keywords: Quercus mongolica, oak wilt disease, anatomical characteristics, tylosis

\section{INTRODUCTION}

A total of $63.2 \%$ of Korea's land is covered with forests, of which $32 \%$ are deciduous forests (Korea Forest Service, 2016). Oak trees, the dominant species with broad leaves, account for $25 \%$ of the deciduous forests. Representative tree species of oaks include Quercus mongolica, $Q$. dentata, $Q$. acutissima, $Q$. var- iabilis, $Q$. aliena, $Q$. serrata they are trees of economic value that have been widely used since ancient times to obtain forestry products (mushrooms) and make musical instruments, fuel materials, oak barrels. However, the damage to oak trees is increasing due to recent changes in climate, new types of diseases, and insect pests.

The first reported case of oak wilt disease to cause

${ }^{1}$ Date Received August 14, 2020, Date Accepted October 14, 2020

2 Division of Timber Engineering, National Institute of Forest Science, 57 Hoegi-ro, Dongdaemu-gu, Seoul 02455, Republic of Korea

${ }^{3}$ Division of Forest Insect Pests and Diseases, National Institute of Forest Science, 57 Hoegi-ro, Dongdaemu-gu, Seoul 02455, Republic of Korea

† Corresponding author: Hyun-Mi LEE (e-mail: leehm2986@korea.kr, ORCID: 0000-0002-1031-3348) 
the sudden death of oak trees in Korea was published in Seongnam, Gyeonggi-do in 2004 (Son et al., 2014). Thereafter, 268,000 trees died due to oak wilt disease in 2012 and 309,000 trees died in 2013, showing an increase of 41,000 trees. Raffaelea quercus-mongolicae, the pathogen that causes oak wilt disease, infiltrates into the sapwood area of oak trees via the insect vector Platypus koryoensis. The infiltrating pathogens multiply and prevent the movement of water, causing the oak trees to desiccate to death (Kim et al., 2009; Kang and Shin, 2017). Furthermore, this disease is primarily found in $Q$. mongolica, $Q$. aliena, and $Q$. serrata and it is also known to often damage other oaks, such as Q. acutissima, Q.variabilis, and Q. dentata (Kim et al., 2016).

The damage caused by oak wilt disease is also occurring at a serious rate in Japan, and it has been reported that a large number of oak trees were killed by the insect vector $P$. quercivorus and pathogen $R$. quercivora (Kubono and Ito, 2002).

Diverse studies have been conducted on oak wood, including those on anatomical, physical, mechanical, and chemical properties (Kim et al., 2006; Han et al., 2015; Kim et al., 2015; Chang et al., 2017; Jeong et al., 2017). On the other hand, studies on trees damaged by oak wilt disease are somewhat limited to pest control, physical, and mechanical characteristics (Kim et al., 2011; Son et al., 2014; Kim et al, 2016; Kim et al., 2020). Although there are studies on trees infected with oak wilt disease, basic anatomical data that can facilitate the utilization of the damaged tree is insufficient. Therefore, in this study, the anatomical characteristics of damaged Q.mongolica (infected and dead) trees were compared with those of sound trees and analyzed to obtain basic data for the utilization of trees damaged by oak wilt disease.

\section{MATERIALS and METHODS}

\subsection{Materials}

To observe the anatomical characteristics of the trees affected by oak wilt disease, two $Q$. mongolica trees (one infected and one dead) were selected, which were confirmed to be damaged by oak wilt disease among the oak trees that grow wild in Dongtan-dong, Hwaseong-si. To compare the anatomical characteristics of infected and dead oak trees with those of sound trees, one sound tree was selected from Chuncheon-si, Gangwon-do. For the experiment, a 3-cm-thick disk was produced immediately after harvesting (Fig. 1), and the chracteristics of tree age, tree ring width, and latedwood proportion are shown in Table 1 .

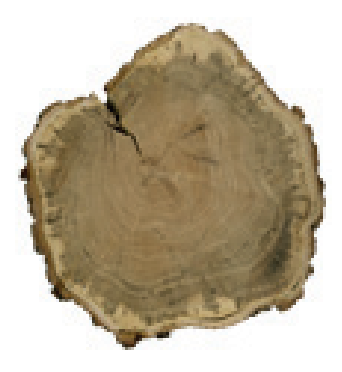

Infested wood

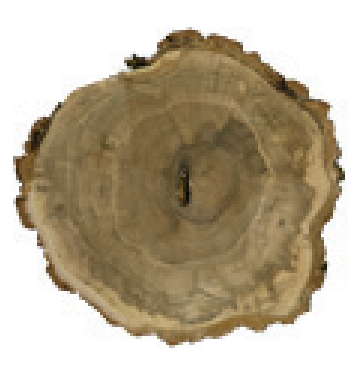

Dead wood

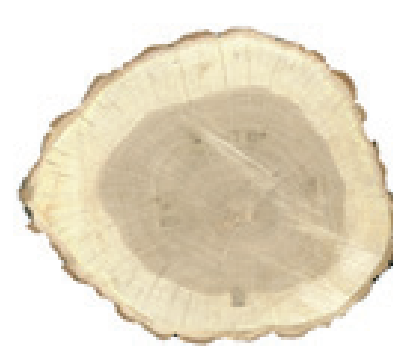

Sound wood

Fig. 1. Disk from infested and dead trees by oak wilt disease, and from a sound tree. 
Comparison of Anatomical Characteristics for Wood Damaged by Oak Wilt and Sound Wood from Quercus mongolica

Table 1. Basic information of infested and dead woods by oak wilt disease, and from a sound wood

\begin{tabular}{cccc}
\hline & Infested wood & Dead wood & Sound wood \\
\hline \hline Tree age (year) & 59 & 55 & 58 \\
Tree ring width (mm) & $2.0 \pm 1.2$ & $2.0 \pm 0.7$ & $2.9 \pm 0.8$ \\
Latewood proportion (\%) & $66.3 \pm 20.6$ & $69.2 \pm 16.2$ & $79.8 \pm 7.8$ \\
\hline
\end{tabular}

\subsection{Methods}

\subsubsection{Optical microscope and scanning electron microscope observation}

The anatomical characteristics of the affected trees were observed using optical and scanning electron microscopes, and the degree of morphological infection was measured. Samples for optical microscopy were prepared by sectioning dead, infected, and sound wood from the pith to the bark at intervals of 10 annual rings. Subsequently, a slice with a thickness of approximately $15-20 \mu \mathrm{m}$ was prepared using a sliding microtome. The prepared slices were stained with $1 \%$ safranine solution and dehydrated with an alcohol solutions (50\%, 70\%, 90\%, 95\%, and 99\%). Permanent slides were then prepared and observed using an optical microscope (Carl Zeiss, DE/Axio Imager A1, Germany).

For the observation with a scanning electron microscope, clean cross-sectional samples were prepared with a microtome at 10 -annual rings intervals. The prepared samples were coated with gold and then observed using a scanning electron microscope (SEMCOX EM-30, COXEM, 20kV).

\subsubsection{Measurement of wood fiber length, diameter of vessel elements, and ratio of tylosis}

To measure the length of wood fiber, a sliver of approximately $1 \mathrm{~cm}$ in length was prepared by separatingthe earlywood and latewood, from the pith of the bark at 5-annual intervals, which were heated and dissociated at $60^{\circ} \mathrm{C}$ in a mixture of hydrogen peroxide and acetic acid in a ratio of 1:1. They were washed with distilled water, dyed with methylene blue. The length of wood fibers of 30 samples of each type of wood were measured using the the DeltaPix (version 5.3.11) program, which were chosen from the annual rings of both earlywood and latewood.

Diameters of vessel elements were measured by determining tangential and radial diameters of each sample $(n=30)$. The tangential and radial diameters were measured by categorizing earlywood and latewood using the annual rings on a cross section at 50x magnification using the prepared permanent slides. The ratio of vessels with tylosis was calculating by estimating the number of vessels with tylosis after measuring the number of 30 vessels from each age group by dividing the wood at 10 ring intervals from the pith to the bark.

\section{RESULTS and DISCUSSION}

\subsection{Anatomical characteristics of wood}

\subsubsection{Cross-sectional characteristics}

Fig. 2 shows the cross section of each annual ring of $Q$. mongolica infected with wilt disease, dead wood, and sound wood imaged using an optical microscope. The cross sections showed that the boundary of the annual ring was distinct due to the porous ring, and the vessels of the earlywood were large and separated and those of the latewood were small and patterned. In the infected, dead, and sound wood, tylosis was often observed in all $\left(10^{\text {th }}-50^{\text {th }}\right)$ annual rings in the vessel, and tyloses in infected and dead wood showed a tendency to appear more frequently than in 


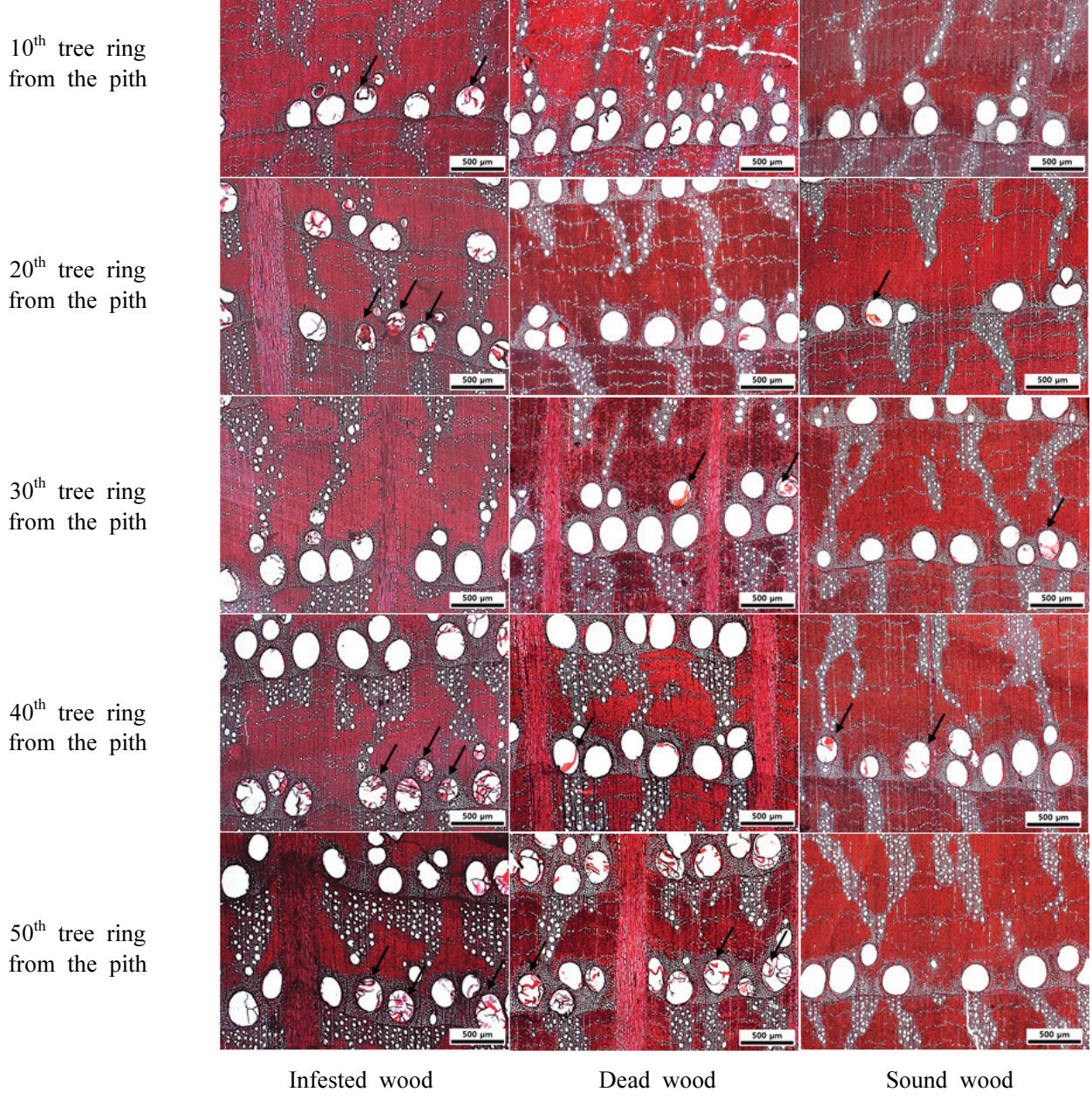

Fig. 2. Optical micrographs on the cross sections of infested, dead, and sound woods by annual rings. Arrow : tylosis in vessel

sound woodin the $40^{\text {th }}$ and $50^{\text {th }}$ annual rings. In the $10^{\text {th }}-30^{\text {th }}$ annual rings of infected, dead, and sound wood, the average ratio of tyloses were $43.3 \%, 33.3 \%$, and $21.1 \%$, respectively, and the average rates of tyloses in the $40^{\text {th }}-50^{\text {th }}$ annual rings were $78.4 \%, 70 \%$, and $11.7 \%$ (Fig. 6), respectively. The results of this experiment showed trends that were consistent with optical microscope results.

Observing the cross sections using the scanning electron micrsope showed that the lumen of the vessel from the $30^{\text {th }}$ and $50^{\text {th }}$ rings of the infected and dead wood had mycelium (Fig. 3). Tylosis, a characteristic of oak trees, is known to block the vessel because the flow parenchyma cells adjacent to the vessel become evaginated due to an injury, while the cells are aging and transitioning into heartwood (Kwon and Kim, 2005; De Micco et al., 2017). Kuroda (2001) observed the characteristics of sapwood in the area infected with 

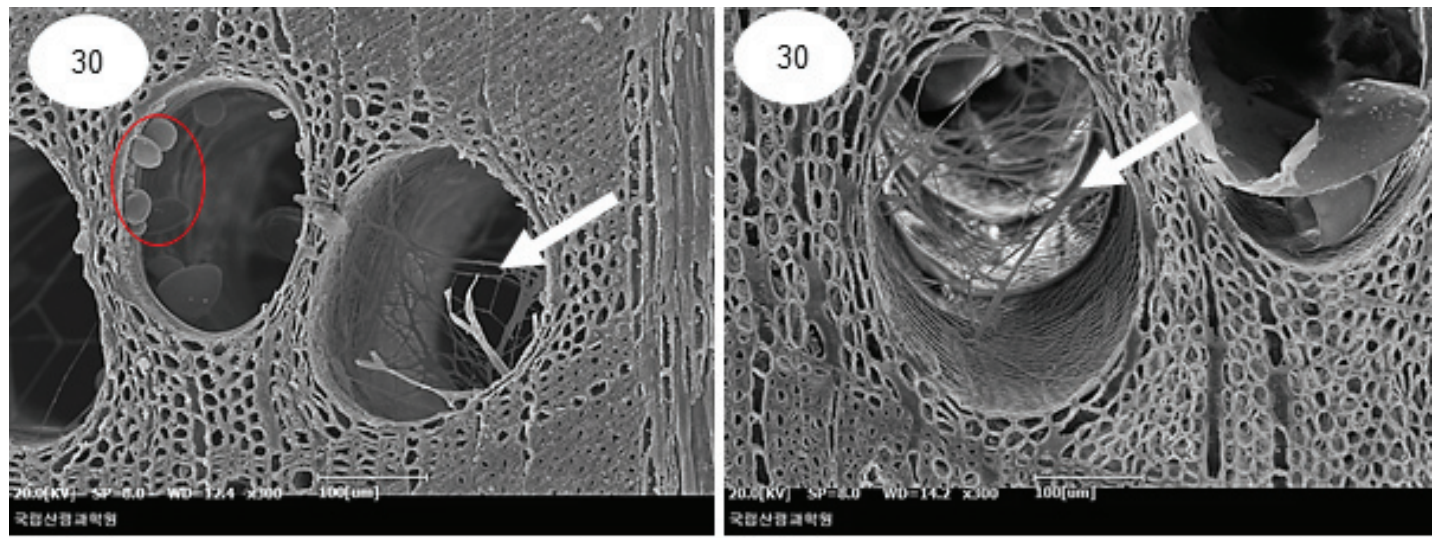

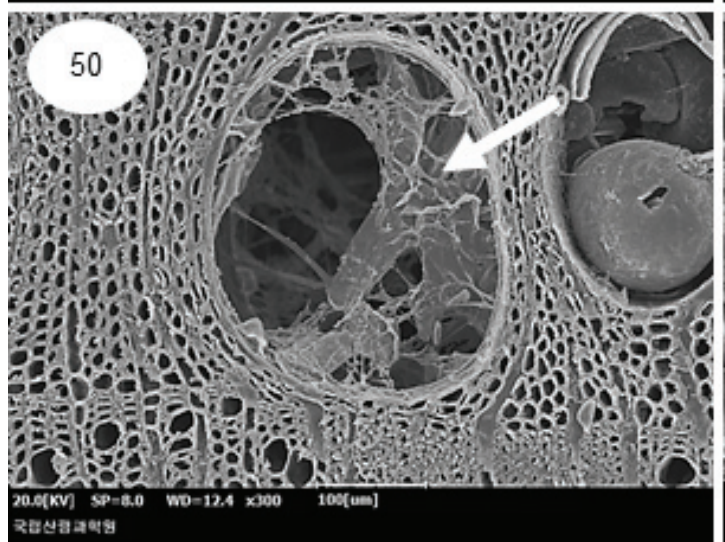

Infested wood

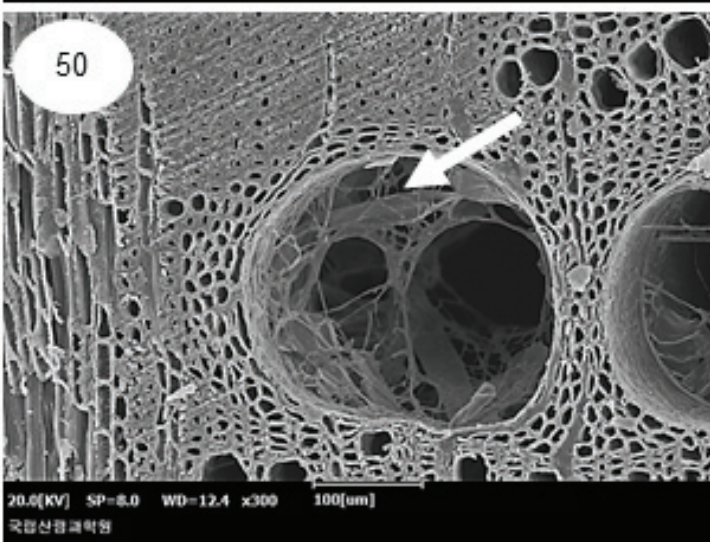

Dead wood

Fig. 3. SEM images on cross section of infested, dead, and sound woods by annual rings.

$30: 30$ th tree ring from the pith, $50: 50$ th tree ring from the pith

Red circle : tylosis bud, White arrow : mycelium

oak wilt disease and found that the distribution of Raffaella sp. and area of discolored sapwood matched, and the function of the vessel was lost. Martíneb et al. (2005) reported that mycelium was observed in the vesselin wood damaged by the pathogen. Therefore, it is believed that the oak wilt disease pathogen mainly penetrates the annual ring of the $30^{\text {th }}$ or $40^{\text {th }}$ sapwood portion from the bark of the tree to block the vessel and prevent the transportation of water.

\subsubsection{Length of wood fiber}

Table 2 shows the length of wood fibers of $Q$. mon- golica infected, dead, and sound wood, separated into earlywood and latewood. The average length of wood fibers in earlywood was $1.20 \mathrm{~mm}$ and $1.24 \mathrm{~mm}$ in the infected and dead wood respectively, and it was slightly longer in sound wood $(1.30 \mathrm{~mm})$. Furthermore, the average length of wood fiber in the latewood was similar to that of the infected and dead wood (1.28 and $1.31 \mathrm{~mm}$, respectively), and was slightly longer in sound wood $(1.36 \mathrm{~mm})$. In all of the infected, dead, and sound wood, wood fiber length tended to increase with increasing annual rings in both earlywood and latewood, and it was found to stabilize in the 20th- 
Woo-Seok JEON $\cdot$ Hyun-Mi LEE $\cdot$ Ji-Hyun PARK

Table 2. Fiber length and vessel dimension of infested, dead, and sound woods

\begin{tabular}{|c|c|c|c|c|c|}
\hline & & Fiber length (mm) & Vessel e & diameter & $\begin{array}{c}\text { Ratio of vessel with tylosis } \\
(\%)\end{array}$ \\
\hline & & \multirow{2}{*}{ Mean } & \multicolumn{2}{|c|}{ Mean } & \multirow{2}{*}{ Mean } \\
\hline & & & $\mathrm{TD}$ & $\mathrm{RD}$ & \\
\hline \multirow{2}{*}{ Infested wood } & EW & $1.20 \pm 0.16$ & $249.4 \pm 29.4$ & $299.6 \pm 37.5$ & 57.3 \\
\hline & LW & $1.28 \pm 0.16$ & $30.1 \pm 4.9$ & $38.5 \pm 6.1$ & - \\
\hline \multirow{2}{*}{ Dead wood } & EW & $1.24 \pm 0.19$ & $238.4 \pm 24.6$ & $286.6 \pm 42.0$ & 48 \\
\hline & LW & $1.31 \pm 0.16$ & $30.5 \pm 5.3$ & $37.8 \pm 6.0$ & - \\
\hline \multirow{2}{*}{ Sound wood } & EW & $1.30 \pm 0.17$ & $241.6 \pm 29.2$ & $278.8 \pm 39.8$ & 17.3 \\
\hline & LW & $1.36 \pm 0.16$ & $27.7 \pm 4.5$ & $35.3 \pm 5.4$ & - \\
\hline
\end{tabular}

EW : Earlywood, LW : Latewood, TD : Tangential direction, RD : Radial direction
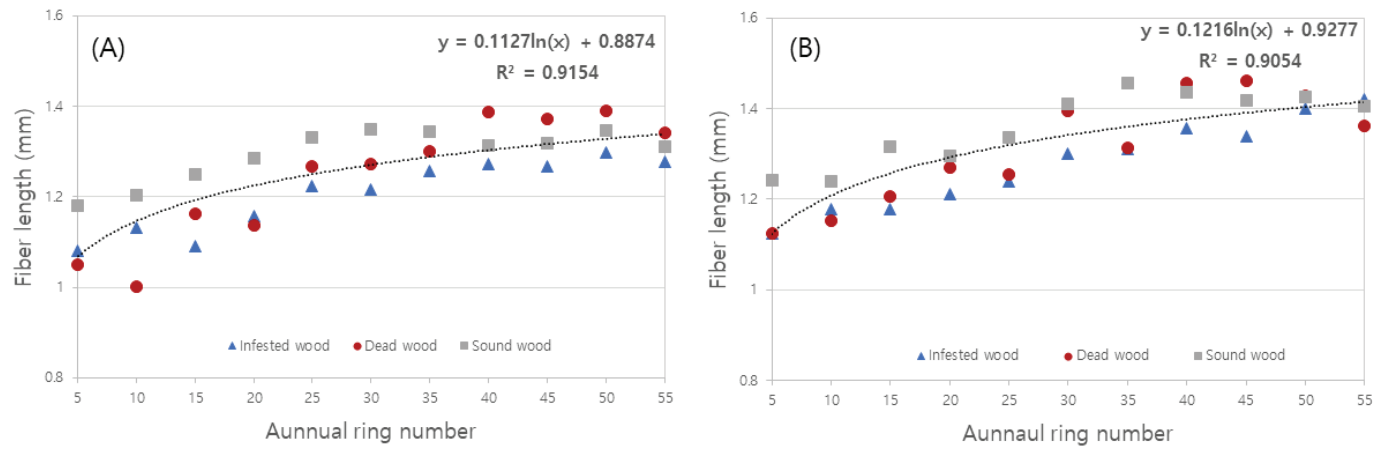

Fig. 4. Fiber length of infested, dead, and sound woods by annual rings.

(A) : Earlywood, (B) Latewood

30th annual rings (Fig. 4). When dividing juvenile wood and mature wood according to the variation of the length of wood fibers, it is believed to be approximately 20-30 annual rings. The wood fiber length of the tested earlywood had an average of $1.17 \mathrm{~mm}$ of juvenile wood and $1.31 \mathrm{~mm}$ of mature wood from the $25^{\text {th }}$ annual ring, whereas the fiber length of the tested latewood had an average of $1.22 \mathrm{~mm}$ for juvenile wood and $1.39 \mathrm{~mm}$ for mature wood. Eom (2015) reported that the average length of wood fibers in Korean Q.mongolica was $981.4 \mu \mathrm{m}$ (range 733$1,323 \mu \mathrm{m})$, which was similar to the results of this study. Meanwhile, the average length of wood fibers in $Q$. acutissima, $Q$. dealbata, Q. fenestrata, Q. lan- ceofolia, and $Q$. semiserrata were 1,199.36 $\mu \mathrm{m}$, 1,439.37 $\mu \mathrm{m}, 1,479.38 \mu \mathrm{m}, 1,509.75 \mu \mathrm{m}$, and 1,389.0 $\mu \mathrm{m}$ (Sharma et al, 2011), respectively. The length of wood fiber of $Q$. Suber was reported to be $1.15 \mathrm{~mm}$ (Sousa et al, 2009), and there was no significant difference from the length of wood fiber in this study. The IAWA Committee (1989) classified the wood fiber length of hardwood into $\leq 900 \mu \mathrm{m}, 900-1,600 \mu \mathrm{m}$, $\geq 1,600 \mu \mathrm{m}$, and the wood fiber length in this study corresponds to $900-1,600 \mu \mathrm{m}$.

\subsubsection{Vessel element diameter and tylosis ratio}

Table 2 shows the results measured by dividing the diameter of vessel elements and ratio of tylosis of in- 
fected, dead, and sound wood of oak trees into earlywood and latewood. The average tangential diameter of the vesselelement of earlywood was the smallest $(234.4 \mu \mathrm{m})$ in the dead wood, the largest was 249.4 $\mu \mathrm{m}$ in the infected wood, the smallest radial diameter was $278.8 \mu \mathrm{m}$ in the sound wood, and the largest was $299.6 \mu \mathrm{m}$ in the infected wood. The average tangential diameter of the vessel element of latewood was the smallest in the sound wood at $27.7 \mu \mathrm{m}$ and that of the dead wood was the largest at $30.5 \mu \mathrm{m}$; the average radial diameter was the smallest in the sound wood $(35.3 \mu \mathrm{m})$ and that of the infected tree was the largest $(38.5 \mu \mathrm{m})$. The radial diameters of the vesselelement in earlywood and latewood was larger than the tangential diameters. The tangential diameter of vessel elements for each annual ring of earlywood, latewood, and radial diameters was the smallest value in 10 annual rings of all of the infected, dead, and sound wood, and the diameter tended to increase as the number of rings increased (Fig. 5). Eom (2015) reported that the average diameter of the tangential line of the vessel element of domestic $Q$. mongolica is $224.0 \mu \mathrm{m}$ (range $=163-286 \mu \mathrm{m})$, and Kim et al. (2002) reported that in sapwood of Korean Q. mongol$i c a$, the tangential diameters of vessel of earlywood and latewood were $245.2 \mu \mathrm{m}$ and $34.0 \mu \mathrm{m}$, respectively, which were similar to the results of this study. Furthermore, in studies of Quercus spp., Sousa et al, (2009) reported that the tangential diameter of the vessel element of $Q$. suber was $133 \mu \mathrm{m}$, and Han et al. (2015) reported that the tangential diameters of the vessel elements of $Q$. rubra were $122 \mu \mathrm{m}$ and 118 $\mu \mathrm{m}$, respectively. The above results were smaller than the diametersof earlywood and latewood of the vessel
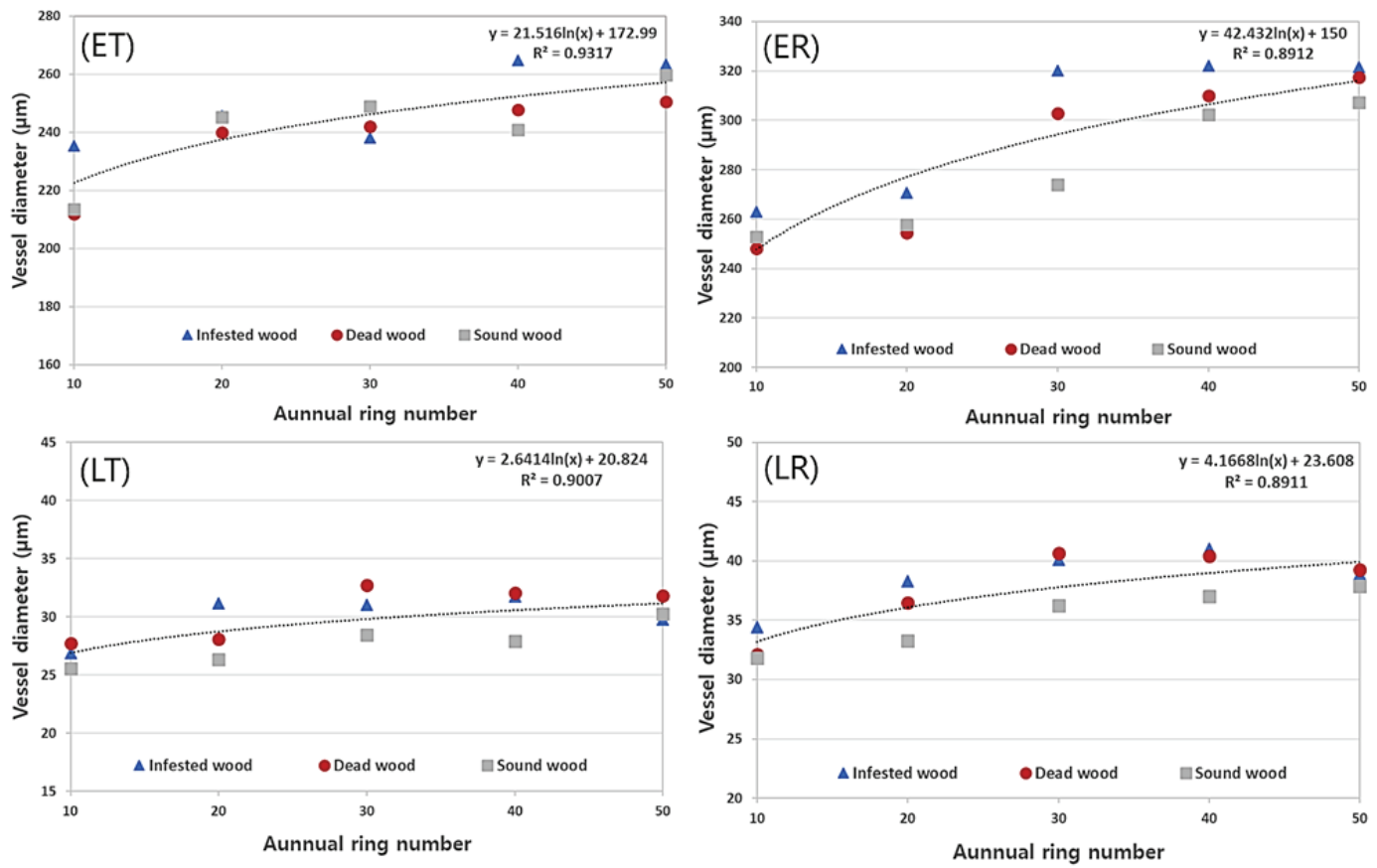

Fig. 5. Vessel element diameter of infested, dead, and sound woods by annual rings.

(ET) : Earlywood - Tangential direction, (ER) : Earlywood - Radial direction

(LT) : Latewood - Tangential direction, (LR) : Latewood - Radial direction 


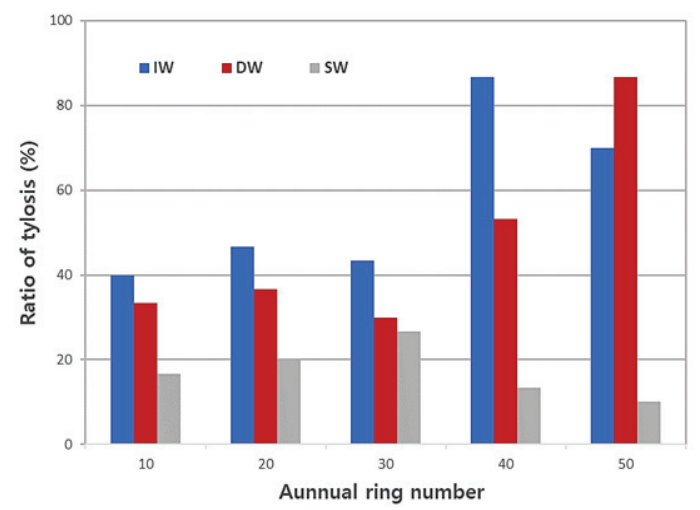

Fig. 6. Vessel element diameter of infested, dead, and sound woods by annual rings.

IW : Infested wood, DW : Dead wood, SW : Sound wood

element in this study. The IAWA Committee (1989) classified the vessel element tangential diameter as $\leq$ $50 \mu \mathrm{m}, 50-100 \mu \mathrm{m}, 100-200 \mu \mathrm{m}$, and $\geq 200 \mu \mathrm{m}$, and the vessel element tangential diameter in this study was $\geq 200 \mu \mathrm{m}$. Regarding vesselelement diameter according to tree age, Lee et al. (2009) reported that both the tangential and radial diameters of vessel elements in Korean chestnut trees gradually increased with increasing tree age, and Leal et al. (2007) investigated the radial variability of the $Q$. suber L. vessel to report that the size of the vessel lumen increased with tree age.

The average ratio of vessel of earlywood including tylosis was the highest in infected wood at approximately $57.3 \%$ and the lowest in sound wood at approximately $17.3 \%$. Furthermore, there was a difference in the ratio of tylosis in the order of infected, dead, and sound wood in the $10^{\text {th }}-30^{\text {th }}$ annual rings, which are considered juvenile wood areas. In the infected and dead woods, it was observed that the ratio of tylosis increased in the $40^{\text {th }}$ and $50^{\text {th }}$ annual rings, which are mature wood (Fig. 6). Therefore, there was a difference in the ratio of tylosis from the heartwood, which is believed to be a difference in the ability to generate tylosis between the sample trees, and it may cause death or infection.

\section{CONCLUSION}

This study compared and analyzed the anatomical characteristics of the damaged and dead wood affected by oak wilt disease and those of sound wood in Korea. Tylosis was frequently observed in the cross sections of infected and dead woods along with mycelium, indicating the degree of infection in the $30^{\text {th }}-50^{\text {th }}$ annual rings. There was no significant difference in wood fiber length and diameter of vessel elements among the tested woods. The wood fiber length increased to 20-30 annual rings, which qualifies as juvenile wood, and showed trends of future stabilization in the mature wood area. Infected wood had the highest average ratio of earlywood vessel including tyloses and sound wood had the lowest. In addition, infected and dead woods had the highest rate of tyloses in the $40^{\text {th }}-50^{\text {th }}$ annual rings, which was judged to be mature wood.

Therefore, there was a confirmed difference in the ratio of tylosis in the areas of juvenile and mature wood in the oak wilt-damaged wood and sound wood of $Q$. mongolica. It is considered that this difference in the tylosis ratio blocks water movement, causing the infection and death of the oak wilt diseased tree. In the future, it is necessary to collect samples with the exact times of infection and death to carefully observe the changes in the oak tissues.

\section{REFERENCES}

Chang, Y.S., Shin, H.K., Kim, S.J., Han, Y.J., Kim, M.J., Eom, C.D., Lee, Y.G., Shim, K.B. 2017. Evaluation of Drying Properties and Yields of Domestic Quercus Species for Enhancing Utilization. Journal of the Korean Wood Science and Technology 45(5): 622-628. 
De Micco, V., Balzano, A., Wheeler, E.A., Baas, P. 2016. Tyloses and gums: a review of structure, function and occurrence of vessel occlusions. IAWA Journal 37(2): 186-205.

Eom, Y.G. 2015. Wood anatomy of Korean species. Published by MEDIA WOOD., Ltd, Seoul, Republic of Korea.

Han, M.S., Lee. J.R., Kim, J.S., Shin, S.J., Kim, B.R. 2015. Studies on wood quality and growth of Quercus rubra in Korea: Anatomical properties. Journal of the Korean Wood Science and Technology 43(4): 421-428.

IAWA Committee. 1989. IAWA list of microscopic features for hardwood identification by an IAWA Committee. E.A. Wheeler, P. Bass \& P.E. Gasson (eds.). IAWA Bull. n. s. 10: 219-332.

Jeong, H.M., Kim, Y.J., Seo, J.W. 2017. Relationships Between Vessel-lumen-area Time Series of Quercus spp. at Mt. Songni and Corresponding Climatic Factors. Journal of the Korean Wood Science and Technology 45(1): 72-84.

Korea Forest Service. 2016. Forest Basic Statistics. pp. 11.

Kang, J.S., Shin, C.S. 2017. Damage Analysis of Oak Wilt According to Geographic Space and Diameter at Breast Height. Journal of Korean Forest Society 106(3): 362-369.

Kuroda K. 2001. Responses of Quercus sapwood to infection with the pathogenic fungus of a new wilt disease vectored by the ambrosia beetle Platypus quercivorus. Journal of Wood Science 47(6): 425-429.

Kim, K.H., Choi, Y.J., Seo, S.T., Shin, H.D. 2009. Raffaelea quercus-mongolicae sp. nov. associated with Platypus Koryoensis on OAK in Korea. Mycotaxon 110: 189-197.

Kim, M.J., Kim, C.K., Chang, Y.S., Lee, H.M., Eom, C.D. 2020. Study on Physical and Mechanical Properties for Wood damaged by Oak wilt. Journal of the Korea Furniture Society 31(1): 1-5.
Kim, N.H., Hwang, W.J., Choi, I.H. 2002. Principal study of Korean oak woods for utilization with whisky aging barrel. The Korea Forestry Energy Research Society 21(2): 43-50.

Kim, N.H., Hwang, W.J., Kwon, S.M., Kwon, G.J., Lee, S.J. 2006. Anatomy Quercus variabilis Charcoal Manufactured at Various Temperatures. Journal of the Korean Wood Science and Technology 34(4): 1-8.

Kim, S.H., Seo, S.Y., Jang, Y.S., Ryu, R., Seo, S.T., Ka, K.H. 2016. Study on Sawdust Bag Cultivation of Shiitake (Lentinula edodes), using Oak WiltDiseased Logs. The Korean Society of Mycology 44(4): 300-306.

Kim, S.J., Lee, S.S., Baek, Y.C., Kim, Y.S., Park, M.J., Ahn, B.J., Cho, S.T., Choi, D.H. 2015. Manufacturing and Feed Value Evaluation of WoodBased Roughage Using Lumber from Thinning of Oak and Pitch Pine. Journal of the Korean Wood Science and Technology 43(6): 851-860.

Kwon, S.M., Kim, N.H. 2005. Annual ring formation in major wood species growing in Chuncheon, $\operatorname{Korea}(\Pi)$ : Formation of resion canals, tyloses and latewood. Journal of the Korean Wood Science and Technology 33(4): 1-8.

Kim, S.W., Jung, J.H., Lamsal, K., Kim, Y.S., Sim, S.J., Kim, H.S., Chang, S.J., Kim, J.K., Kim, Kim, K.S., Lee, Y.S. 2011. Control Efficacy of Nanosilver Liquid on Oak Wilt Caused by Raffaelea sp. in the Field. The Korean Society of Plant Pathology 17(2): 136-141.

Kubono, T., Ito, S.I. 2002. Raffaelea quercivora sp. nov. associated with mass mortality of Japanese oak, and the ambrosia beetle (Platypus quercivorus). Mycoscience 43(3): 255-260.

Leal, S., Sousa, V.B., Pereira, H. 2007. Radial variation of vessel size and distribution in cork oak wood (Quercus suber L.). Wood Science and Technology 41(4): 339-350. 
Lee, S.H., Kwon, S.M., Lee, S.J., Lee, U., Kim, M.J., Kim, N.H. 2009. Radial variation of anatomical characteristics of chestnut wood(Castanea crenata) grown in Korea: Vessel element and ray. Journal of the Korean Wood Science and Technology 37(1): 19-28.

Martínez, Á.T., Speranza, M., Ruiz-Dueñas, F.J., Ferreira, P., Camarero, S., Guillén, F., Martínez, M.J., Gutiérrez, A., Río Andrade, J.C.D. 2005. Biodegradation of lignocellulosics: Microbial, chemical, and enzymatic aspects of the fungal attack of lignin.
Interational Microbiology 8: 195-204.

Sharma, M., Sharma, C.L., Kharkongor, B.M., Carter, M.J. 2011. Wood anatomical variations in some species of Quercus of Meghalaya. Journal of the Indian Academy of Wood Science 8(2): 152-157.

Son, S.Y., Seo, S.T., Park, J.H. 2014. Control Efficacy of Fungicide Injection on Oak Wilt in the Field. Research in Plant Disease 20(4): 295-298.

Sousa, V.B., Leal, S., Quilhó, T., Pereira, H. 2009. Characterization of cork oak (Quercus suber) wood anatomy. IAWA Journal 30(2): 149-161. 


\title{
APPENDIX
}

\author{
(Korean Version)
}

\section{참나무시들음병 신갈나무 피해목과 건전목의 해부학적 특징 비교}

초록 : 본 연구에서는 참나무시들음병에 감염된 신갈나무의 기초자료를 확보하기 위하여, 해부학적 특징을 비교·분석하고자 하였다. 해부학적 특징을 비교하기 위해, 감염목, 고사목 및 건전재 신갈나무를 수에서부터 10 50번째 연륜까지 10 연륜 단위로 광학현미경과 주사전자현미경을 이용하여 관찰하였다. 목섬유 길이는 수에서부터 5 연륜 단위로 측정하였고, 도관요소 직경 및 타일로시스를 포함한 도관의 비율은 10 연륜별로 측정하였다. 횡단면 관찰 결과, 감염목과 고사목에서는 도관 내강에서 티일로시스와 함께 균사체가 관찰되었다. 목섬유 길이 및 도관요소 직경은 조사목 간 큰 차이를 보이지 않았다. 목섬유 길이는 미숙재 부위인 20 30연륜 이후 안정화되는 경향을 보였다. 타일로시스를 포함한 도관의 평균 비율은 감염목이 가장 높았고 특히, 감염목과 고사목은 40 50연륜에서 타일로시스의 비율이 가장 높았다. 이를 통하여, 참나무시들음병 피해목과 건전재 간에 큰 차이는 타일로시스의 비율로 생각되며, 피해목 이용에 있어 기초자료로 활용 가능할 것이라 사료된다.

\section{1. 서 론}

우리나라의 국토 $63.2 \%$ 는 산림으로 구성되어 있으며, 이 중 32\%는 활엽수림이다(Korea Forest Service, 2016). 활엽수림의 우점종인 참나무류가 활엽수림에서 차지하는 비율은 $25 \%$ 이다. 참나무류의 대표 수종으로는 신갈나무, 떡갈나무, 상수리나무, 굴참나무, 갈참나무 및 졸참나무가 있으며 예로부터 악기재, 연료재, 오크통, 임산물(버섯) 등으로 널리 사용되고 있는 경제 수종 중 하나이다. 그러나, 최근 기후변화 및 신종병해충 등으로 인해 참나무류의 피해가 늘고 있는 실정이다.

국내에서 참나무류의 급격한 고사 원인이 참나무시들음병이라고 최초로 보고된 사례는 2004년에 경기도 성남시에서 발표한 것이다(Son et al., 2014). 이후 2012년에는 268,000본이 참나무시들음병으로 고사하였으며, 2013년에는 41,000본이 증가한 309,000 본이 고사하였다. 참나무시들음병을 일으키는 병원균인 Raffaelea quercus-mongolicae는 매개충인 광름긴나무좀 (Platypus koryoensis)에 의해 참나무류 변재부에 침투하게 되는데, 참나무류가 말라 죽는 이유는 침투된 병원균이 번식하면서 수분의 이동을 막기 때문이다(Kim et al., 2009; Kang and Shin, 2017). 또한 이 병은 참나무류 중 신갈나무, 갈참나무, 졸참나무 에서 주로 발견되며 그 외 상수리나무, 굴참나무, 떡갈나무에도 종종 피해를 받는 것으로 알려져 있다(Kim et al., 2016).

참나무시들음병의 피해는 일본에서도 심각한 수준으로 발생되고 있으며, 매개충 P. quercivorus 및 병원균 R. quercivora에 의해 대량의 떡갈나무가 고사하였다고 보고하였다 (Kubono and Ito, 2002).

참나무류 목재에 관한 선행 연구 주제에는 해부, 물리, 역학 및 화학적 특성 등 매우 다양하다(Kim et al., 2006; Han et al., 2015; Kim et al., 2015; Chang et al., 2017; Jeong et al., 2017). 반면, 참나무시들음병 피해목에 관한 연구로는 방제, 물리 및 역학적 특성(Kim et al., 2011; Son et al., 2014; Kim et al., 2016; Kim et al., 2020) 등으로 다소 제한적이다. 이와 같이 참나무시들음병 피해목에 관한 연구들이 수행되었지만, 피해목의 활용을 위한 해부학적 기초 데이터는 부족한 실정이다.

따라서, 본 연구에서는 참나무시들음병 피해목의 활용을 위한 기초 데이터 확보를 위하여 신갈나무 피해목(감염목, 고사목)과 건전재의 해부학적 특징을 비교·분석하였다.

\section{2. 재료 및 방법}

\section{1. 공시재료}

참나무시들음병 피해목의 해부학적 특징을 관찰하기 위해 화성시 동탄동에서 자생하고 있는 참나무류 중 참나무시들음병이 확인된 신갈나무(Quercus mongolica) 감염목(infested tree) 1 본과 고사목(dead tree) 1 본을 선발하였으며, 건전목의 해부학적 특징과 비교하기 위해 강원도 춘천시에서 건전목(sound tree) 1 본을 선발하였다. 공시재료는 벌채 직후 $3 \mathrm{~cm}$ 두께의 디스크를 제작하였으며(Fig. 1), 연륜, 연륜폭 및 만재율의 특성은 Table 1과 같다. 


\section{2. 실험방법}

\subsection{1. 광학현미경 및 주사전자현미경 관찰}

광학현미경과 주사전자현미경을 통해 해부학적 특징을 관찰하고, 피해목의 형태학적 감염 정도를 확인하고자 하였다. 광학현 미경 관찰을 위해 고사목, 감염목 및 건전재를 수에서부터 수피부를 향해 10 연륜 간격으로 구분하여 시편을 제작하였다. 이후, 활주식 마이크로톰(sliding microtome)을 이용하여 $15 \sim 20 \mu \mathrm{m}$ 두께의 절편을 제작하였다. 제작된 절편을 $1 \%$ safranine 용액으로 염색하고 알코올 시리즈 $(50 \%, 70 \%, 90 \%, 95 \%, 99 \%)$ 로 탈수 후, 영구프레파라트를 제작하여 광학현미경(Carl Zeiss, Germany) 으로 관찰하였다.

주사전자현미경 관찰은 연륜별 시편을 마이크로톰으로 깨끗한 단면을 제작하였다. 제작된 시편은 gold 코팅 후, 주사전자현미 경(SEMCOX EM-30, COXEM, 20kV)으로 관찰하였다.

\subsection{2. 목섬유 길이, 도관요소 직경 및 타일로시스의 비율 측정}

목섬유 길이 측정을 위해 수에서부터 수피부를 향해 5 연륜 간격으로 조재와 만재를 구분하여, 길이 약 $1 \mathrm{~cm}$ 의 sliver를 제작 후 과산화수소와 아세트산을 $1: 1$ 로 혼합하여 $60^{\circ} \mathrm{C}$ 온도로 가열하고 해리시켰다. 이후 증류수로 세척한 뒤, 메틸렌블루 (Methylene blue)로 염색하고, DeltaPix (version 5.3.11) 프로그램을 이용하여 연륜별, 조·만재부에서 각각 30개씩 목섬유 길이를 측정하였다.

도관요소 직경은 제작한 영구프레파라트를 이용하여 50 배율의 횡단면 상을 연륜별로 조만재부를 구분하여 접선 및 방사방향 직경을 각각 30 개씩 측정하였다. 타일로시스를 포함한 도관의 비율은 수에서부터 수피부를 향해 10 연륜 간격으로 구분하여 각 연륜의 조재부에서 30 개의 도관의 수를 측정한 뒤, 타일로시스를 포함한 도관의 수를 측정하여 비율을 계산하였다.

\section{3. 결과 및 고찰}

\section{1. 목재해부학적 특징}

\subsection{1. 횡단면 특징}

Fig. 2는 참나무시들음병 감염목, 고사목 및 신갈나무 건전재의 연륜별 횡단면을 광학현미경으로 관찰한 사진이다. 횡단면 관찰 결과, 환공재로 연륜 경계가 뚜렷하였으며, 조재부 도관은 대형·단독으로 존재하고, 만재부에서는 소형·문양상으로 관찰되 었다. 감염목, 고사목 및 건전재에서 모든(10 50)연륜에서 도관내에 타일로시스가 종종 관찰되었고, 감염목과 고사목은 40번째 와 50 번째 연륜에서도 건전재에 비해 타일로시스가 빈번히 나타나는 경향을 보였다. 감염목, 고사목 및 건전재의 $10 ~ 30$ 번째 연륜에서 타일로시스의 평균 비율은 각각 $43.3,33.3,21.1 \%$ 이며, $40 \sim 50$ 번째 연륜에서는 $78.4,70.0,11.7 \%$ 의 평균값을 보였다 (Fig. 6). 이는 광학현미경 결과와 유사한 경향을 보였다.

주사전자현미경 관찰 결과, 감염목과 고사목의 30 번째 연륜 및 50 번째 연륜에서 도관 내강에 균사체가 관찰되었다(Fig. 3). 참나무류의 특징 중 하나인 타일로시스(tylosis)는 세포의 노화 및 심재화가 발생할 때, 외상 등에 의해 도관에 인접한 유세포가 팽출되어 도관내강으로 스며들어 도관을 폐색 시키는 것으로 알려져 있다(Kwon and Kim, 2005; De Micco et al., 2017). Kuroda (2001)은 참나무시들음병의 변재 부위의 특성을 관찰하여, Raffaella sp. 의 분포와 변색한 변재 부위가 일치하며, 도관의 기능을 상실했다고 보고하였고, Martíneb et al. (2005)는 균에 의해 피해를 받은 목재에서 도관 내에 균사체가 관찰되었 다고 보고하였다. 따라서, 참나무시들음병 병원균은 주로 나무의 수피부에서 30 또는 40 번째 변재부 연륜에 침투하여 도관을 폐색시키고 수분의 이동을 막는 것으로 사료된다.

\subsection{2. 목섬유 길이}

Table 2 는 감염목, 고사목 및 건전재 신갈나무의 목섬유 길이를 조·만재로 구분하여 측정한 결과이다. 조재부 평균 목섬유 길이는 감염목과 고사목이 각각 $1.20 \mathrm{~mm}, 1.24 \mathrm{~mm}$ 로 유사한 값을 보였고, 건전재는 $1.30 \mathrm{~mm}$ 로 다소 길었다. 또한 만재부 평균 목섬유 길이에서도 감염목과 고사목이 각각 $1.28 \mathrm{~mm}, 1.31 \mathrm{~mm}$ 로 비슷한 값을 보였고, 건전재는 $1.36 \mathrm{~mm}$ 로 다소 길었다. 감염목, 고사목 및 건전재 모두 조만재에서 연륜 증가에 따라 목섬유 길이가 증가하는 경향을 보였고, $20 ~ 30$ 연륜에서 안정화되 었다(Fig. 4). 목섬유 길이의 변이에 따라서 미숙재와 성숙재를 구분하였을 때, 약 $20 ~ 30$ 연륜 부근이라고 생각된다. 조사목의 조재 목섬유 길이는 25 번째 연륜을 기준으로 미숙재 $1.17 \mathrm{~mm}$, 성숙재 $1.31 \mathrm{~mm}$ 의 평균값을 나타냈으며, 만재 목섬유 길이는 미숙재 $1.22 \mathrm{~mm}$, 성숙재 $1.39 \mathrm{~mm}$ 의 평균값을 보였다. Eom (2015)은 국내산 신갈나무의 목섬유 길이가 평균 $981.4 \mu \mathrm{m}$, 
$733 \sim 1,323 \mu \mathrm{m}$ 범위로 보고하였고 이는 본 연구 결과와 유사하였다. 한편, $Q$. acutissima, $Q$. dealbata, Q. fenestrata, $Q$. lanceofolia 및 $Q$. semiserrata 는 각각 1,199.36 $\mu \mathrm{m}, 1,439.37 \mu \mathrm{m}, 1,479.38 \mu \mathrm{m}, 1,509.75 \mu \mathrm{m}$ 및 1,389.0 $\mu \mathrm{m}$ (Sharma et al, 2011), Q. Suber는 $1.15 \mathrm{~mm}$ (Sousa et al, 2009)로 참나무속(Quercus spp.)의 목섬유 길이가 보고되고 있으며, 본 연구의 목섬유 길이와 큰 차이가 없었다. IAWA Committe (1989)는 활엽수재의 목섬유 길이를 $\leq 900 \mu \mathrm{m}, 900-1,600 \mu \mathrm{m}, \geq 1,600$ $\mu \mathrm{m}$ 로 구분하였고, 본 연구의 목섬유 길이는 $900 \sim 1,600 \mu \mathrm{m}$ 에 해당하였다.

\subsection{3 도관요소 직경 및 타일로시스의 비율}

Table 2는 감염목, 고사목 및 건전재 신갈나무의 도관요소 직경 및 타일로시스의 비율을 조만재로 구분하여 측정한 결과이다. 조재 도관요소의 평균 접선 직경은 고사목이 $234.4 \mu \mathrm{m}$ 로 가장 작은 반면, 감염목 $249.4 \mu \mathrm{m}$ 로 가장 컸고, 평균 방사 직경은 건전재가 $278.8 \mu \mathrm{m}$ 로 가장 작았으며, 감염목이 $299.6 \mu \mathrm{m}$ 로 가장 컸다. 만재 도관요소 평균 접선 직경은 건전재가 $27.7 \mu \mathrm{m}$ 로 가장 작은 반면, $30.5 \mu \mathrm{m}$ 로 고사목이 가장 컸으며, 평균 방사 직경은 건전재가 $35.3 \mu \mathrm{m}$ 로 가장 작았고, 감염목이 $38.5 \mu \mathrm{m}$ 로 가장 컸다. 조만재 도관요소 직경은 방사 직경이 접선 직경보다 더 크게 나타났다. 연륜별 도관요소 직경은 감염목, 고사목 및 건전재 모두 조·만재 접선·방사 직경이 10 연륜에서 가장 작은 값을 보였고, 연륜이 증가함에 따라 직경이 증가하는 경향을 보였다(Fig. 5). Eom (2015)은 국내산 신갈나무의 도관요소 접선 직경이 평균 $224.0 \mu \mathrm{m}, 163 \sim 286 \mu \mathrm{m}$ 범위라고 보고하였으며, Kim et al. (2002)은 국내산 신갈나무의 변재에서 조재 및 만재 도관 접선 직경을 각각 $245.2 \mu \mathrm{m}$ 및 $34.0 \mu \mathrm{m}$ 라고 보고하여, 본 연구 결과와 유사하였다. 그 외에 참나무속 (Quercus spp.)의 이전 연구를 보면, Sousa et al, (2009)은 Q. suber 의 도관요소 접선 직경은 $133 \mu \mathrm{m}$ 보고하였으며, Han et al. (2015)은 Quercus rubra 의 도관요소 조재 및 만재 접선 직경을 각각 122 $\mu \mathrm{m}$ 및 $118 \mu \mathrm{m}$ 라고 보고하였다. 상기 결과 들은 본 연구의 도관요소 직경 보다 작은 값을 나타냈다. IAWA Committe (1989)는 도관요소 접선 직경을 $\leq 50 \mu \mathrm{m}, 50-100 \mu \mathrm{m}, 100-200 \mu \mathrm{m}, \geq 200 \mu \mathrm{m}$ 로 분류하였고, 본 연구의 도관요소 접선 직경은 $\geq 200$ $\mu \mathrm{m}$ 에 해당하였다. 수령에 따른 도관요소 직경에 관하여, Lee et al. (2009)은 국내산 밤나무 도관요소의 직경이 접선·방사 직경 모두 수령의 증가에 따라 점차 증가하는 경향을 보였다고 보고하였으며, Leal et al. (2007)은 Quercus suber L. 도관의 방사방향 변이성을 조사하여, 도관 내강의 크기는 수령이 증가함에 따라 증가한다고 보고하였다.

타일로시스를 포함한 조재 도관의 평균 비율은 감염목이 약 $57.3 \%$ 로 가장 높았으며, 건전재가 약 $17.3 \%$ 로 가장 낮았다. 또한 미숙재 부위로 판단되는 10 번째 연륜부터 30 번째 연륜에서 감염목, 고사목 및 건전재 순으로 타일로시스의 비율이 차이가 있었고, 감염목과 고사목은 성숙재 부위인 40 및 50 번째 연륜에서 타일로시스의 비율이 높아지는 것이 관찰되었다(Fig. 6). 따라서, 타일로시스의 비율은 심재부에서부터 차이가 있었고, 이는 조사목 상호 간 타일로시스의 생성 능력에 차이가 있다고 생각되며, 고사 또는 감염의 원인이 될 수 있을 것이라 판단된다.

\section{4. 결 론}

본 연구는 국내 참나무시들음병에 감염된 신갈나무 피해목 및 고사목과 건전목의 해부학적 특징을 비교·분석하였다. 감염목 및 고사목의 횡단면에서 타일로시스가 빈번히 관찰되었고, $30 \sim 50$ 번째 연륜에서는 감염 정도를 알 수 있는 균사체가 관찰되었 다. 목섬유 길이 및 도관요소 직경은 조사목 간 큰 차이를 보이지 않았으며, 목섬유 길이는 미숙재 부위인 20 30 연륜까지 증가하다가 이후 성숙재 부위에서 안정화되는 경향을 보였다. 타일로시스를 포함한 조재 도관의 평균 비율은 감염목이 가장 높았으며, 건전재가 가장 낮았다. 또한 감염목과 고사목은 성숙재로 판단되는 40 50번째 연륜에서 타일로시스 비율이 높았다.

따라서, 참나무시들음병 피해목과 건전재 신갈나무는 미숙재와 성숙재 부위에서 타일로시스의 비율에 차이가 있는 것으로 확인되었다. 이러한 타일로시스 비율의 차이는 수분의 이동을 막아 참나무시들음병 피해목의 감염 및 고사에 영향을 미쳤을 것으로 추정된다. 추후, 고사 및 감염의 시기가 명확한 시료를 채취하여, 참나무류 조직 변화의 면밀한 관찰이 필요할 것으로 사료된다. 